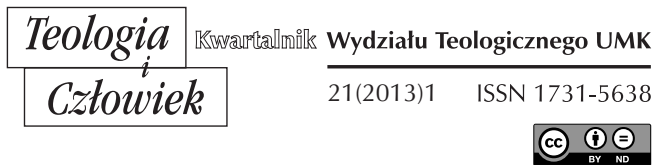

ADAM JÓZEF SOBCZYK MSF*

KAZIMIERZ BISKUPI

\title{
HEZYCHIA JAKO OWOC MODLITWY JEZUSOWEJ WEDŁUG PISM WYBRANYCH OJCÓW Z XIII/XIV WIEKU Z GÓRY ATHOS
}

DOI: http://dx.doi.org/10.12775/TiCz.2013.006

Człowiek z natury jest istotą religijną. Od samego początku swego istnienia poszukuje skutecznej metody utrzymania więzi z Bogiem. Bogactwo praktyk religijnych jest wielkie. Istota ludzka, która szuka jakiejś odpowiedniej dla siebie formy relacji ze Stwórcą, może ją odnaleźć i dopasować do swojego wyznania, temperamentu, wrażliwości, warunków życia. Zwrócił na to uwagę bł. Jan Paweł II, który z jednej strony zachęcał do poznania i ponownego przemyślenia własnego duchowego dziedzictwa chrześcijan także z innych Kościołów, z drugiej zaś przestrzegał katolików otwierających się na rozmaite dalekowschodnie techniki ascetyczne i rodzaje medytacji ${ }^{1}$. Niestety, obecnie obserwuje się spore zainteresowanie, także ze strony chrześcijan, różnymi, często niebezpiecznymi dla duchowego rozwoju praktykami.

* Dr hab. Adam Józef Sobczyk - kapłan ze Zgromadzenia Misjonarzy Świętej Rodziny - adiunkt Zakładu Teologii Duchowości UMK w Toruniu. Od 2007 roku członek Międzynarodowej Komisji Formacyjnej Zgromadzenia Misjonarzy Świętej Rodziny, od 2009 roku członek korespondent Polskiego Stowarzyszenia Teologów Duchowości.

${ }^{1}$ Por. Jan Paweł II, List apostolski. Rosarium Virginis Mariae, Kraków 2002, nr 5; tenże, Przekroczyć próg nadziei, Lublin 1994, s. 80. 
Z tego względu wydaje się uzasadnione podjęcie tematu modlitwy Jezusowej jako sprawdzonej przez wieki formy relacji z Bogiem, która stanowi realną alternatywę dla wszelkich innych praktyk spoza świata chrześcijańskiego. Krytyczne omówienie tej modlitwy, powinno zachęcić do jej praktykowania i pomóc $\mathrm{w}$ drodze do zjednoczenia $\mathrm{z}$ Bogiem. Zwłaszcza, że do tej pory zagadnienie nie zostało zbyt obszernie opracowane. Istnieja, co prawda, prace podejmujące temat modlitwy Jezuso$w^{2}{ }^{2}$, ale nie ukazują wprost jej wpływu dla uzyskania hezychii. Z tego względu, celem artykułu będzie przedstawienie, na podstawie nauczania Ojców z Góry Athos, czym jest hezychia i jak można ją osiągnąć przez praktykowanie modlitwy Jezusowej.

Wybór akurat takiego przedziału czasowego został podyktowany dwoma przesłankami: po pierwsze, wiek XIII/XIV zawiera bogactwo nauczania na temat Modlitwy Jezusowej, gdyż tworzą w nim najwybitniejsi znawcy tematu i mistrzowie życia duchowego (św. Grzegorz Palamas, Nicefor Pustelnik zwany Hezychastą, Kalikst i Ignacy Ksantopuloi). Po drugie ramy artykułu nie pozwalają na szersze opracowanie tego zagadnienia. W tym artykule analizy badawcze zostaną oparte na Filokaliach w języku polskim opracowanych przez księdza Józefa Naumowicza (Kraków 2004).

\section{PRAKTYKA MODLITWY JEZUSOWEJ JAKO PODSTAWA HEZYHII}

Modlitwa Jezusowa, należąca do modlitwy myślnej, kontemplacyjnej, zwanej także modlitwą serca, to charakterystyczny rodzaj duchowości i mistyki prawosławnej, skoncentrowany na wzywaniu imienia Jezusa. Jej fundamentem jest krótkie i nieustannie powtarzane biblijnego wezwania: „Panie Jezu Chryste, Synu Boży, zmiłuj się nade mną, bo jestem grzesznikiem!". Jest ona wypełnieniem nakazu Chrystusa, że:

${ }^{2}$ Na ten temat por. J. Lafrance, Modlitwa serca, Kraków 2000; Mnich Kościoła Wschodniego, Modlitwa Jezusowa, Kraków 1993; G.A. Maloney, Modlitwa serca, Włocławek [b.r.]; J. Serr, O. Clement, Modlitwa serca, Lublin 1993.

3 „Filokalia”, po prostu umiłowanie piękna. Składa się z fragmentów pism Ojców Wschodnich i zawiera $\mathrm{w}$ sobie filozofię działania i kontemplacji. $\mathrm{W}$ ten sposób ukazuje metody, dzięki którym umysł może zostać oczyszczony, oświecony i udoskonalony. Stanowi wielkie i znaczące dzieło zwane „sumą Modlitwy Jezusowej” albo „duchową szkołą modlitwy wewnętrznej". 
„Zawsze powinni się modlić i nie ustawać” (por. Łk 18,1). Towarzyszy temu odczuwanie stałej obecności Pana oraz poczucie własnej grzeszności, połączone z prośbą o litość. Modlitwa ta została rozpowszechniona na Zachodzie dzięki dziełu anonimowego autora: „Szczere opowieści pielgrzyma przedstawione jego ojcu duchownemu" ${ }^{\prime \prime}$.

Ojcowie z Góry Athos utrzymują, że modlitwa Jezusowa jest podstawą hezychii. Jednak podkreślają trynitarne źródła pokoju serca. Nawiązuje do tego m.in. św. Maksym Kausokalybos, który zwraca szczególną uwagę na pneumatologiczny wymiar modlitwy Jezusowej. Akcentuje rolę Trzeciej Osoby Trójcy Świętej, która obdarza łaską głębokiego i niewzruszonego spokoju duszy (por. Ga 5,22) .

Modlitwa Jezusowa ma swoje biblijne podstawy. Wynikają one z faktu, że zarówno w Piśmie Świętym, jak i w całej tradycji żydowskiej, występuje silny kult Bożego Imienia Jahwe (por. Wj 23,21; Jl 2,26; Mi 4,5; Za 13,9). Z kolei, w Nowym Testamencie i tradycji chrześcijańskiej, analogiczna cześć jest oddawana Najświętszemu Imieniu Jezus (por. Łk 18,38; Dz 2,21; 4,12; Flp 2,9-10). Treść modlitwy Jezusowej kształtowała się stopniowo i dojrzewała przez wiele lat. Posługiwano się w tym okresie różnym fragmentami tekstów Starego Testamentu, a następnie także z ksiąg nowotestamentalnych, a ściślej mówiąc ewangelicznych. Teksty te cytowano $\mathrm{w}$ jednym zdaniu. Ostatecznie modlitwa Jezusowa została ukonstytuowana na podstawie trzech ewangelijnych fragmentach: błagania niewidomego żebraka Bartymeusza u bram Jerycha: „Jezusie, Synu

${ }^{4} \mathrm{~W}$ monastycyzmie wschodnim Ojcowie Pustyni posługiwali się hezychastyczną metodą modlitewną polegającą na czuwaniu w ciszy serca i odmawianiu Modlitwy Jezusowej. Por. E. Smykowska. Modlitwa Jezusowa, „Nurt SVD” 2 (1998), s. 111-117; M. Szram, Modlitwa w chrześcijaństwie, w: Encyklopedia katolicka, t. 12, red. S. Wilk, Lublin 2008, kol. 1530; Z. Pałubska, Modlitwa Jezusowa, w: Leksykon duchowości katolickiej, red. M. Chmielewski, Lublin-Kraków 2002, s. 549-550.

${ }^{5}$ Autor Opowieści pielgrzyma jest nieznany. Opat Paisij (+1883) z klasztoru św. Michała w Kazaniu, przepisał ją, od któregoś ze starców z Góry Athos, który też nie był jej autorem. Tajemnicze jest także pochodzenie drugiej części Opowieści pielgrzyma, wydanej w 1911 roku w Moskwie. Jest to anonimowe dzieło, wydane w Kazaniu nad Wołgą około 1870 roku, pod nazwą: Szczere opowieści pielgrzyma przedstawione jego ojcu duchownemu. Kolejne wydania nastąpiły w późniejszych latach, w kilku językach, również po polsku pod nazwą: Szczere opowieści pielgrzyma przedstawione jego ojcu duchownemu, Poznań 1988; por. J. Serr, O. Clement, Modlitwa serca, s. 8; Mnich Kościoła Wschodniego, Modlitwa Jezusowa, s. 71; G. A. Maloney, Modlitwa serca, s. 35.

${ }^{6}$ Por. J. Naumowicz (red.), Filokalia, s. 319-324; H. Nussbaumer. Odkryć w sobie mnicha. Pielgrzymując na górę Athos, red. M. Szafrańska-Brandt, Warszawa 2008, s. 41-87. 
Dawida, ulituj się nade mną" (por. Mk 10,47; Łk 18,38), modlitwy celnika, proszącego: „Boże, miej litość dla mnie grzesznika” (por. Łk 18,13) oraz wołania Kananejki: „Ulituj się nade mną, Panie, Synu Dawida!” (por. Mt 15,22). Na ich podstawie, daje się wyznaczyć dwie części składowe modlitwy Jezusowej: „Panie Jezu Chryste, Synu Boży” oraz „zmiłuj się nade mną"

Autorzy prawosławni, widzą korzenie modlitwy Jezusowej w praktyce i duchowości starożytnych, chrześcijańskich mnichów wschodnich, starających się realizować nakaz: „nieustannie się módlcie!” (por. 1 Tes 5,17). Przeglądając jednak ogólny zarys dziejów duchowości filokalicznej od IV do XIV wieku, można wyróżnić w nim cztery wzajemnie przenikające się okresy piśmiennictwa ascetyczno-mistycznego, z głównymi ośrodkami w Egipcie, na Synaju, w Konstantynopolu i na Górze Athos. Dotyczą one zasadniczo dwóch aspektów: rozwoju myśli ascetycznej i historii praktykowania modlitwy Serca ${ }^{8}$.

Genezą modlitwy Jezusowej rozumianej jako podstawa dla hezychii był zawarty $\mathrm{w}$ Ewangeliach styl życia Jezusa na pustyni (por. Mt 4,1-11; Łk 4,1-13). Postawa Syna Bożego zachęciła znaczną liczbę osób, które szukały ciszy, spokoju i samotności, do szukania Boga poprzez modlitwę, ascezę, w skrajnie trudnych warunkach. Przykład Chrystusa i jego późniejszych kontynuatorów stanowi zatem podstawę zarówno powołania pustelniczego, jak i owocu modlitwy powstającej $\mathrm{w}$ takich warunkach, jakim była hezychia. Do najbardziej znanych wschodnich monastycznych autorów, opisujących to zagadnienie w swoich dziełach należeli ojcowie egipscy, na czele ze św. Antonim Wielkim, Makarym, Ewagriuszem, a także, związanymi z Azją Mniejszą, Palestyną i Grecją, jak Markiem Eremita, czy Diadochem z Fotyki. W swoich pismach zawarli oni wskazania dotyczące praktykowania tej modlitwy dla wszystkich chrześcijan?.

Istotną rolę dla rozpowszechnienia modlitwy Jezusowej na zachodzie odegrał św. Jan Kasjan. Jego dzieła są owocem wieloletniego życia

7 Por. tamże, s. 27-28; B. Kondrusik, Modlitwa Jezusowa - mantra chrześcijańska, „Przegląd Powszechny”, Warszawa 1984, s. 196-201; E. Smykowska, Modlitwa Jezusowa, s. 111-117; J. Serr. O. Clement, Modlitwa serca, s. 8-9.

${ }^{8}$ Szerzej por. J. Chryssavgis, W sercu pustyni. Duchowość Ojców i Matek Pustyni, red. T. Dekert, Kraków 2007, s. 16-100.

${ }^{9}$ Por. J. Naumowicz, Filokalia, s. 8-9; C. Morrisson (red.), Świat Bizancjum, t. I: Cesarstwo wschodnio-rzymskie 330-641, Kraków 2007, s. 276. 
pośród Ojców Pustyni w Egipcie ${ }^{10}$. Powszechnie uznaje się go za osobę łączącą duchowość Wschodnią i Zachodnią pierwotnego monastycyzmu. Najcenniejsze teksty Kasjana dotyczą modlitwy, jej praktyki i przygotowania się do niej. Jako jeden z pierwszych określił on fundamentalne elementy modlitwy ciągłej, jednozdaniowej, monologicznej i zachęcał do częstego odmawiania krótkiego wersetu Psalmu: „Boże, wejrzyj ku wspomożeniu memu, Panie, pośpiesz ku ratunkowi memu" (por. Ps 70,2). Przez co nakreślił pewien rys modlitwy Jezusowej, prowadzący do spokoju serca ${ }^{11}$.

Kolejnym miejscem, w którym kształtowała się modlitwa Jezusowa, będąca fundamentem hezychii była Góra Synaj. W klasztorze św. Katarzyny, który powstał w VI wieku, dokonała się przemiana życia pustelniczego na wspólnotowe, jednak z zachowaniem ideałów pustelniczych. Ciekawym owocem takiej zmiany i pewną syntezą zarazem obu stylów życia dla duchowości monastycznej, było położenie akcentu na bardziej intensywne poszukiwanie głębokiego wyciszenia zwanego hezychią. Skoro nie można było żyć osobno, na pustyni, to w celu doskonałego naśladowania Chrystusa, należało zwrócić się jeszcze bardziej ku swemu wnętrzu, w nim szukając ciszy i obcowania z Bogiem. Takie podejście $\mathrm{w}$ naturalny sposób stanowiło podłoże dla stworzenia i realizacji modlitwy Jezusowej, która miała dać ów spokój wewnętrzny modlącemu się mnichowi.

Za ojca hezychazmu powszechnie uważany jest św. Jan Klimak. Poprzez dzieło pt. Drabina do raju przyczynił się on do rozwoju modlitwy Jezusowej. Przedstawił w nim trzydzieści stopni duchowej drogi do doskonałości. Na każdym szczeblu, opisał sposoby zdobywania chrześcijańskich cnót oraz walkę z ośmioma głównymi namiętnościami dotyczącymi zmysłów. Podał także, okoliczności wprowadzające w stan wyciszenia i modlitwy. Jego myśl, podjęli później także inni pisarze synajscy: Hezychiusz, Filoteusz i Grzegorz. W taki sposób doszło do powstania trybu życia nacechowanego czuwaniem, kontrolą nad myślami

${ }^{10}$ Uważa się go za osobę, która zaszczepiła życie monastyczne na Zachodzie i jedynego, spośród łacińskich pisarzy ascetycznych, którego pisma zostały zestawione w Filokalii. Por. J. Kasjan, Rozmowy z Ojcami, t. I: Rozmowy I-X, Kraków 2002, s. 5. 19-20; tenże, Rozmów dwadzieścia cztery. Rozmowa XI-XXIV, t. VII, Poznań 1929, s. 191.

${ }^{11}$ Por. J. Kasjan, Rozmowy z Ojcami, s. 19-20; tenże, Rozmów dwadzieścia cztery, s. 1; J. Naumowicz, Filokalia, s. 99. 
i odmawianiem modlitwy Hezychii, którą można praktykować nie tylko w klasztorze, lecz również i poza jego murami ${ }^{12}$.

Trzeci okres piśmiennictwa ascetycznego, po egipskim i synajskim, rozwinął się $\mathrm{w}$ klasztorach konstantynopolitańskich. Jego cechą charakterystyczną, w porównaniu chociażby z okresem synajskim, było podkreślenie aspektu praktycznego życia mniszego. We wspólnym przebywaniu, mnisi modlili się, pracowali, studiowali i kopiowali literackie dzieła. Życie ascetyczne, łączyło się z mistycznym, stwarzając warunki dla rozwoju hezychazmu. Zauważalny jest również silny akcent położony na liturgię. Takie podejście stanowiło doskonałą podstawę do realizacji modlitwy Jezusowej dla większego wyciszenia i spokoju serca mnicha, który swoje ciało zmęczył całodzienną pracą ${ }^{13}$.

Do przedstawicieli tego kierunku należą między innymi: bizantyński mistyk, św. Symeon Nowy Teolog oraz Niketas Stetatos. Pierwszy z nich praktykował biblijne i krótkie, ale ciągłe modlitewne wezwania: „Boże, zmiłuj się nade mną, grzesznikiem!” oraz „Synu Boży, zmiłuj się nade mną; Panie zmiłuj się!” (por. Mk 10,47 n; Łk 18,13). Będąc przełożonym klasztoru Studytów w Konstantynopolu pozostawił po sobie bogatą spuściznę literacką opartą na mistycznych wizjach nadprzyrodzonego, niebiańskiego światła, porównywalnego do opisanej w Ewangelii światłości oblicza Jezusa Chrystusa na Taborze (por. Łk 9,29). To duchowe przeżycie Symeona, stało się zasadniczym wątkiem w rozwoju modlitwy monologicznej ${ }^{14}$.

Z kolei Niketas Stetatos, przełoży w klasztorze Studios w Konstantynopolu, napisał dzieło zwane Centurie praktyczne, gnostyckie $i$ teologiczne. Zawarł $\mathrm{w}$ nim rozważanie trzech stopni życia duchowego oraz towarzyszącą im modlitwę Hezychii i pamięć o Bogu. Nazwał je trzema zwierciadłami doskonałości i świątobliwego życia. Wymienił je kolejno jako praxis, w którym opisał praktykowanie cnót w celu opanowania namiętności, theoria, gnósis, dotyczące oczyszczenia umysłu i kontemplacji oraz theologia, w którym wyjaśnił mistyczne poznanie Boga, miłość do Niego i sposób doskonałego życia. Chociaż nie mówił

12 Por. J. Naumowicz, Filokalia, s. 11-13. 183.

${ }^{13}$ Por. tamże, s. 151.

${ }^{14}$ Jego pisma popularne wśród mnichów z Góry Athos, stanowią doskonały pomost pomiędzy wielkimi Ojcami Kościoła Wschodniego i Hezychastami. Por. J. Naumowicz, Filokalia, s. 15. 229-230. 236; T. Matus, Joga i Modlitwa Jezusowa. Doświadczenie w wierze, Kraków 2003, s. 14-15. 
wprost o modlitwie Jezusowej, to jednak przygotował dla niej teologiczne uzasadnienie ${ }^{15}$.

W czwartym okresie piśmiennictwa ascetycznego, centrum życia duchowego skoncentrowane było na Górze Athos. W analizowanym $\mathrm{w}$ tym artykule przełomie XIII i XIV wieku nastąpiło tam odrodzenie duchowości hezychastycznej i teologii bizantyjskiej oraz rozkwit modlitwy Jezusowej. Dokonało się to głownie dzięki zaangażowaniu wielkich ojców filokalicznych, do których należy zaliczyć: Teoleptosa z Filadelfii, Nicefora Pustelnika, Maksyma Kausokalibosa, Kaliksta i Ignacego Ksantopuloi oraz Grzegorza z Synaju i Grzegorza Palamasa.

Do rozpowszechnienia modlitwy Jezusowej przysłużyło się również powstanie Filokalii, będącej sumą bizantyjskiej, ascetyczno-mistycznej myśli. Przez to dzieło Święta Góra stała się ośrodkiem popularyzacji prawosławnej duchowości hezychastycznej i miejscem intensywnego praktykowania tej modlitwy ${ }^{16}$.

Tworzący tam Nicefor był prekursorem metody łączenia oddechu z wymową słów modlitwy. Zestawił pouczenia Świętych Ojców o duchowej trzeźwości, uwadze i modlitwie oraz opracował metodę uwagi, prowadzącej ku modlitwie Serca ${ }^{17}$.

Jego uczeń Teoleptos napisał antologiczną pracę, w której ściśle i wiernie przedstawił zasadę „ukrytego działania w Chrystusie”. Jego dzieło było przeznaczone dla tych, którzy chcieli mieć syntetyczny wykład duchowej filozofii chrześcijańskiego Wschodu. W swojej sumie dotyczącej nauczania pustelników, umieścił także pouczenia o konieczności czujności, nieprzerwanej pamięci o Bogu, modlitewnym skupieniu, przylgnięciu umysłu do Boga, o duchowej skrusze, medytacji i nieustannym wzywaniu Najświętszego Imienia Jezus ${ }^{18}$.

${ }^{15}$ Por. J. Naumowicz, Filokalia, s. 247.

${ }^{16}$ Potwierdzeniem tej tezy są także inne dzieła Ojców, traktujące o Modlitwie Ducha, uwadze, potrzebie czujności i sposobach, które mają pomóc „sprowadzić umysł do serca". Por. J. Naumowicz, Filokalia, s. 16-19.

17 Por. tamże, s. 265.

18 Teoleptos żył w latach 1250-1322. Prowadził mnisze i ascetyczne życie na Górze Athos, a następnie został wezwany na biskupstwo w Filadelfii. Manuskrypt Teoleptosa, zawierał wyjaśnienia o działaniu nous, umysłu, diánoia, lógos, rozumu i pneuma, ducha. Autor uważa, że „umysł”, w przeciwieństwie do „rozumu”, nie opiera się na poznaniu teoretycznym, lecz oświecony łaską przyjmuje prawdę Bożą na sposób intuicyjny. Jest miejscem i narzędziem kontemplacji Boga, skupienia i poznania. Por. J. Naumowicz, Filokalia, s. 297. 
Podobnie Grzegorz z Góry Mojżesza był krzewicielem modlitwy Jezusowej. Zachęcał w swoich pismach do żywej i mistycznej więzi z Bogiem. Swoje doświadczenia modlitewne przekazał mnichom na Górze Athos i w ten sposób dzieląc się nauką, którą zdobył na Synaju i Krecie na temat modlitwy Jezusowej, przyczynił się do rozwoju hezychii ${ }^{19}$.

Z kolei inny spośród wielkich Hezychastów, św. Grzegorz Palmas, odznaczył się apologią duchowości hezychastycznej wobec zarzutów mnicha Barlaama z Kalabrii. W tym celu napisał swoje klasyczne dzieło: „Triady. W obronie świętych Hezychastów”. W nim wyłożył naukę o partycypacji ciała w modlitwie, metodach psychofizycznych, „sprowadzaniu umysłu do serca" i celu modlitwy kontemplacyjnej ${ }^{20}$.

O wzniosłym znaczeniu i wartości modlitwy Jezusowej prowadzącej do hezychii i zjednoczenia z Bogiem, nauczał także św. Maksym Kausokalybos. On jako pierwszy w tamtym czasie, podał wzór połączenia pamięci o Jezusie Chrystusie i Najświętszej Maryi Pannie ${ }^{21}$.

Do ukonstytuowania ostatecznej formy modlitwy Jezusowej przyczynili się dwaj wielcy asceci z Góry Athos, Kalikst i Ignacy Ksantopuloi. Napisali oni: Centurie, "Sto Rozdziałów”, traktat o fundamentalnym, hezychastycznym ascetyzmie, dotyczącym praktyki Modlitwy Ducha ${ }^{22}$. Ułożyli również regułę życia dla Hezychastów, w której centrum znajduje się modlitwa Serca, wypowiadana w rytmice oddechu, za pomocą słów: „Panie Jezu Chryste, Synu Boży, zmiłuj się nade mną”. W ten sposób stworzyli solidne podstawy do ujmowania modlitwy Jezusowej jako podstawy hezychii²3.

${ }^{19}$ Cztery z jego pism zostały zamieszczone w Filokalii: „Rozdziały bardzo pożyteczne"; "O wyciszeniu i modlitwie"; "O wyciszeniu i dwóch sposobach modlitwy"; „W jaki sposób hezychasta ma siadać do modlitwy i nie wstawać zbyt szybko”. Por. J. Naumowicz, Filokalia, s. 283.

${ }^{20}$ Por. J. Naumowicz, Filokalia, s. 305-307. 316; A. Siemianowski, Tomizm, a Palamizm. Wokót kontrowersji doktrynalnych chrześcijańskiego Wschodu i Zachodu w średniowieczu, Poznań 1998, s. 11. 32.

${ }^{21}$ Potwierdzeniem tego jest jego rozmowa z Grzegorzem Synajskim, znajdująca się w biografii z końca XIV wieku, napisanej przez Teofana z Vatopedi w klasztorze Góry Athos. Maksym, odpowiadając na pytania Grzegorza, wyjawił tajemnicę, że otrzymał od Boga, za wstawiennictwem Najświętszej Maryi Panny, szczególną łaskę modlitwy oraz nieustanną pamięć umysłu o Chrystusie i Bogarodzicy. Por. J. Naumowicz, Filokalia, s. 319.

${ }^{22}$ Na temat wartości „Centurii” zobacz więcej: Mnich Kościoła Wschodniego. Modlitwa Jezusowa, s. 48-50.

${ }^{23}$ Por. J. Naumowicz, Filokalia, s. 325-326. 


\section{ISTOTA HEZYCHII}

Praktykowanie modlitwy Jezusowej przynosi, zdaniem Ojców z Góry Athos, wiele duchowych owoców. Można wśród nich wymienić między innymi: znane na chrześcijańskim wschodzie przebóstwienie ${ }^{24}$ oraz wzrost $\mathrm{w}$ miłości, która przyjmuje najrozmaitsze odcienie: przebaczenia, miłosierdzia, cierpliwości względem bliźnich. Ważnym owocem modlitwy Jezusowej jest hezyhia ${ }^{25}$. Szukając odpowiedzi na pytanie o jej istotę, należy najpierw wyjaśnić jej znaczenie, następnie przybliżyć nurt hezychastyczny, w którym powstała oraz przedstawić najważniejsze postaci zasłużone dla jej genezy i rozwoju.

Hezychia to stan spokoju, polegający na wyciszeniu ciała, serca i ducha. To swoiste wewnętrzne skupienie i milczenie. Najlepiej jej znaczenie oddaje greckie słowo $\eta \sigma v \chi \imath$ (hesychia), które oznacza odpoczynek, chwile wytchnienia, spokój, ciszę, samotne miejsce i pustkowie. Hezychia należy do tradycji Kościoła Wschodniego. Jest zrodzona i kształtowana z doświadczenia i nauki Ojców począwszy już od IV wieku, co doprowadziło w XIII/XIV wieku do powstania Hezychazmu, jako nurtu duchowości monastycznej rozwijanego na Górze Athos, związanego z psychosomatycznymi metodami praktyki modlitwy Jezusowej. Doświadczając stanu apatheia, nieczułości, beznamiętności i nienaruszoności, Hezychaści dążyli do kontemplacji światłości Bożej, utożsamianej ze światłem Przemienienia z Góry Tabor ${ }^{26}$. Hezychaści nazywają ją stanem umysłu, stałą czujnością (por. Ps 57,8) i absolutną koncentracją na Bogu. Urealnia ona całkowite nawrócenie grzesznika do Stwórcy, jego powrót i zjednoczenie z Nim.

24 "Serce" jest miejscem spotkania z Bogiem Trójjedynym, który przemawia do swojego stworzenia, uzdrawia je i przemienia w "nowe stworzenie” (por. J 3,3). Człowiek wierzący, powtarzając słowa modlitwy: „Panie Jezu Chryste, Synu Boży, zmiłuj się nade mną grzesznikiem!", przekształca w świątynię cały świat. Dzieje się tak, ponieważ do miłości Boga i wejścia w mistyczny stan przebóstwienia jest zobowiązany każdy chrześcijanin. Por. G. Maloney, Modlitwa, s. 23; P. Evdokimov, Kobieta i zbawienie świata, Poznań 1991, s. 90.

25 Por. G. Maloney, Modlitwa, s. 50-51. 133-134.

${ }^{26}$ Por. J. Naumowicz, Filokalia, s. 12; J. Y. Leloup, Stowa z Góry Athos, Warszawa 1986, s. 17-20; T. Spidlik, Człowiek Boga. U źródet życia zakonnego, Kraków 2006, s. 33; H. Krańczuk, Mnisi Góry Athos o duchowości prawosławnej, Hajnówka 1995, s. 140-145; T. Matus, Joga i Modlitwa Jezusowa, s. 11. 
Hezychazm jako jeden z nurtów duchowości wschodniej, wyrósł z doświadczenia Ojców Pustyni ${ }^{27}$. Szczególnie zasłużony dla tego nurtu był Ewagriusz z Pontu. Żyjąc wiele lat na pustyni egipskiej, podkreślał i rozpowszechniał, głównie, umysłowy akcent modlitwy monologicznej. Co istotne, nie utożsamiał on pojęcia "umysł" z intelektem, lecz pojmował je jako عíḱ́v $\theta \varepsilon o v ́$ - podobieństwo Boże (por. Rdz 1,26 n). Wyjaśnił, że modlitwa jest środkiem zharmonizowania $z$ wolą Bożą i pomaga przejść od gnosis, wiedzy do jedności z Chrystusem. Dla hezychazmu zasłużył się przede wszystkim uzasadnieniem tezy, że normalnym stanem ducha ludzkiego jest widzenie Boga w świetle, w klimacie jedności, pokoju i zupełnej harmonii. Owe dwa komponenty, wewnętrzny pokój serca i światło, stały się ogniwem ruchu hezychastycznego i zostały później rozwinięte przez świętych mnichów, Symeona Nowego Teologa i Grzegorza Palamasa ${ }^{28}$.

Hezychia jako owoc modlitwy Jezusowej stanowi niejako dziedzictwo i zarazem świadectwo duchowego życia mnichów Świętej Góry. Na podstawie ich pism można stwierdzić, że polega na jedności ciała, ducha i duszy, gwarantującej modlącemu się mnichowi wewnętrzną ciszę i pokój. Dokonuje się dzięki łasce Boga oraz otwarciu człowieka na nią. Wymaga także systematycznego odmawiania modlitwy Jezusowej, wytrwałego praktykowania ascezy właściwej zakonnikom i stosowania należnej techniki oddychania po przyjęciu odpowiedniej postawy ciała ${ }^{29}$. W duchowości Ojców filokalicznych pojęcie hezychia pojawia się wielokrotnie, co oznacza, że jest dla nich bardzo istotne. Utożsamiają go nie tylko ze stanem serdecznego pokoju i uwagi, które są jedynie etapem pośrednim życia duchowego mnicha. Podkreślają, że przez praktykę modlitwy Jezusowej hezychia ma doprowadzić do osiągnięcia stanu nieustannego przebywania z Panem - trwania w Bogu ${ }^{30}$. 1983, s. 18.

${ }^{27}$ Por. J. Klinger, O istocie Prawostawia. Wybór pism, K. Rybacka (red.), Warszawa

${ }^{28}$ Symeon, zwany także Nowym Teologiem lub Nowym Janem Ewangelistą, kierowany miłością w duchowym poznawaniu Jezusa Chrystusa, zapoczątkował nową tendencję mistyczną. Por. Benedykt XVI, Mistrzowie duchowi. Ojcowie i pisarze średniowiecza, Poznań 2011, s. 24; T. Spidlik, Człowiek Boga, s. 14; G. Maloney, Modlitwa, s. 24-28.

${ }_{29}$ Por. G. Maloney, Modlitwa, s. 12. 14. 21-23; Лествииа возводящая на небо. Преподобного отиа натего Иоанна игумена Синайской горы, Полтавская 2001, s. 424.

${ }^{30}$ Św. Jan Klimak opisał stopnie osiągania tego stanu w Drabinie do raju. Stopień dwudziesty siódmy poświęcił wyciszeniu, natomiast dwudziesty ósmy modlitwie związanej z wyciszeniem. Por. J. Klimak, Drabina do raju, s. 294-318; J. Naumowicz, Filokalia, s. 183-196. 
Według Grzegorz z Synaju głęboka duchowość hezychastyczna prowadzi do przemiany wewnętrznej mnicha. Kształtuje ją wyciszenie, wypełnianiu Bożych przykazań oraz ciągłe wzywaniu imienia Jezusa. W ten sposób przejawia się moc Ducha Świętego otrzymana na chrzcie ${ }^{31}$. Tę drogę życia duchowego będącą istotą hezychii oddaje także inna nazwa modlitwy Jezusowej - modlitwa Ducha. Pod wpływem działania Trzeciej Osoby Najświętszej Trójcy Świętej mnich osiąga stan skupienia uwagi i „wprowadzania umysłu do serca”. Na tym etapie „umysł, będąc w sercu” nieustannie woła: „Panie Jezu Chryste, Synu Boży, zmiłuj się nade mną grzesznikiem!". Taka postawa przyczynia się do wzrostu cnót: miłości, radości, pamięci o Bogu, cierpliwości i pokoju serca ${ }^{32}$.

Odnośnie do praktycznego sposobu odmawiania modlitwy Jezusowej, prowadzącej do hezychii, Teoleptos z Filadelfii zalecał potrójny sposób wypraszania Bożego błogosławieństwa, łaski i duchowego pokoju. Twierdził, że należy błagać słowem, wypraszać milczeniem i żebrać, padając na twarz. Zauważył przymioty modlitwy Jezusowej, która, jego zdaniem, jest wystarczająco czysta i prosta, by połączyć w sobie wszystkie trzy sposoby trwania przed Panem. Tłumaczył to zjawisko faktem, że podczas modlitwy Jezusowej następuje wzajemne przenikanie rozumu, umysłu i ducha modlącego się człowieka (por. Mt 18,20). Rozum wzywa imienia Jezus, umysł zwraca się ku Bogu, natomiast duch wyraża uniżenie, pokorę, skruchę i miłość. W ten sposób modlitwa Jezusowa, będąca źródłem hezychii, zespala duchowe władze w człowieku, łącząc ludzką duszę z Trójcą Najświętszą. Poprzez przeniknięty modlitwą, czysty intelekt, serce i duch zostają napełnione niebiańską radością i niewysłowionym pokojem ${ }^{33}$. Hezychia zatem jako owoc modlitwy Jezusowej

${ }^{31}$ Por. J. Naumowicz, Filokalia, s. 284-295; Лествица возводящая на небо, s. $424-428$.

${ }^{32}$ Nicefor Pustelnik, zwany Hezychastą-Samotnikiem napisał dzieło O czujności i straży serca. Opracowanie Nicefora, składa się z trzech części: o „metodzie” życia duchowego wprowadzającej oranta w stan beznamiętności; o metodzie uzyskiwania „uwagi”, określanej jako „wprowadzanie umysłu do serca”, a także o metodzie nieustannego wzywania Najświętszego Imienia Jezus. Mimo głosów krytycznych ze strony Barlaam i innych przeciwników hezychazmu; "metodę” Nicefora, popierał Grzegorz Palmas i Ojcowie Filokaliczni XIV wieku, Ignacy i Kalikst Ksantopuloi, którzy zaprezentowali ją na początku swego dzieła: „Sto Rozdziałów” przyczyniając się do jej rozpowszechnienia wśród mieszkańców Athosu. Por. J. Naumowicz, Filokalia, s. 265-281.

${ }_{33}$ Teoleptos nie przedstawiał Modlitwy Jezusowej jako zastrzeżonej dla wąskiego grona pustelników (hezychastów), lecz ujmował ją jako ważny element wspólnotowego życia zakonnego i eklezjalnego. Por. J. Naumowicz, Filokalia, s. 297-302. 
ma duże znaczenie dla rozwoju życia duchowego człowieka, dlatego po ukazaniu jej istoty zasadnym wydaje się wskazanie praktycznych sposobów jej nabywania.

\section{SPOSOBY NABYWANIA HEZYCHII}

Powiedziano wyżej, że źródłem modlitwy Jezusowej jest Najświętsza Trójca, ze szczególnym uwzględnieniem uświęcającego działania Ducha Świętego. Natomiast Kalikst i Ignacy Ksantopuloi uważali, że podstawą duchowego pokoju jest mocna wiara, życie sakramentalne oraz pełnienie dobrych uczynków. Rozpatrywali zatem możliwość nabywania pokoju serca oddolnie tzn. od strony człowieka. Uważali, że bez życia chrześcijańskiego opartego na modlitwie, sakramentach i trwaniu w łasce uświęcającej niemożliwe jest nabycie hezychii. Tylko takie duchowe podłoże powoduje, że źródłem każdej modlitwy, a w sposób szczególny modlitwy Jezusowej, będącej niejednokrotnie walką i zmaganiem, jest pełne wiary przyzywanie imienia Pana Jezusa (por. J 15,5). Owocem tego duchowego trudu jest Boży dar pokoju i miłości w sercu ${ }^{34}$.

Z kolei Autor dzieła Metoda świętej modlitwy $i$ uwagi, proponuje trzy formy modlitwy chrześcijaninowi pragnącemu doświadczyć wewnętrznego pokoju, wyciszenia namiętności i duchowego odrodzenia. Pierwszą z nich jest rozmyślanie nad Pismem Świętym i kierowanie swojego umysłu ku Bogu; drugą wysiłek uwalniania się od natrętnych myśli i namiętności; zaś trzecia polega na tak zwanym „wprowadzaniu umysłu wewnątrz serca". Wszystkie wspomniane formy rozmowy z Bogiem wzajemnie na siebie oddziaływają i są ze sobą wewnętrznie połączone ${ }^{35}$.

Jednakże nie sam ludzki wysiłek jest decydującym czynnikiem osiągnięcia głębokiego, mistycznego pokoju, lecz łaska Ducha Świętego. Grzegorz z Synaju, na kartach Filokalii, podaje istotne wskazówki dla chrześcijan pragnących korzystać z modlitwy Jezusowej. Zwraca uwagę na konieczność otrzymania łaski Bożej oraz doświadczenia działania samego Ducha Świętego. Uważa, że otrzymana na chrzcie świętym łaska, została przysłonięta pomroką namiętności, dlatego podkreśla konieczność

${ }^{34}$ Por. tamże, s. 326.

${ }^{35}$ Filokalia wskazuje na Symeona Nowego Teologa (zm. 1022), według innych świadectw to Nicefor Pustelnik z końca XIII wieku lub inny współczesny mu autor. Por. J. Naumowicz, Filokalia, s. 253-264. 
jej stopniowego oczyszczania przez sumienne wypełnianie przykazań Bożych i praktykowanie modlitwy Jezusowej ${ }^{36}$.

Grzegorz, posiadając łaskę duchowej kontroli umysłu i serca, dążył w swoim życiu duchowym do osiągnięcia stanu "czystej modlitwy". Swoje doświadczenie chciał przekazać mnichom na Górze Athos. Uważał bowiem, że w życiu monastycznym mnisi zapomnieli o kontemplacji. $\mathrm{Z}$ tego powodu zaproponował wprowadzenie praktyki odmawiania modlitwy Jezusowej. Wkrótce Góra Athos stała się centrum praktykowania tego sposobu relacji z Bogiem. Dla Synaity, Modlitwa Serca czyni duszę płomienną i radosną, rodzi skruchę, pokorę, pomaga unicestwić złe myśli i wprowadza w stan wyciszenia i pokoju. Wzór Grzegorza przejęli inni Ojcowie hezychastyczni, którzy traktowali modlitwę monologiczną, jako drogę do osiągnięcia duchowej doskonałości, pozwalającej na osobiste, mistyczne obcowanie z Bogiem ${ }^{37}$.

Innym nauczycielem hezychii, który wskazał metodę „wprowadzania umysłu do serca" był Grzegorz Palamas. Zawarł w niej połączenie duchowego wysiłku z przyjęciem określonej postawy ciała. Swoją metodę oparł na tezie, że serce jest siedzibą myśli (por. Mt 15,11.19) i pierwszym, cielesnym organem. W związku z tym, radził, by w miarę możliwości, „Zwinąć" ciało jak gdyby w kłębek. Dzięki takiej pozycji ciała umysł powinien szybciej przeniknąć $\mathrm{w}$ głębiny serca. O specyfice tej metody świadczy fakt, że zewnętrznej postawie ciała winna towarzyszyć wewnętrzna, polegająca na nieustannym czuwaniu i podporządkowaniu ciała duchowi (por. Pwt 15,9). Tylko w taki sposób umysł przekaże sercu odpowiednie treści modlitewne. Palamas, jako doświadczony mistrz modlitwy zauważa, że gdy się regularne stosowanie tej postawy modlitewnej wraz z nieustanną troską o postęp na drodze ku duchowemu wyciszeniu i pokojowi, wyrabia u modlącego się umiejętność mimowolnego i bez wysiłkowego wstępowania $\mathrm{w}$ siebie $^{38}$.

${ }^{36}$ Por. tamże, s. 283-284.

37 Św. Jan Klimak wyznał: „Imieniem Jezusa będziesz smagać wrogów. Nie ma bowiem potężniejszej broni na ziemi i na niebie. Dziełem duchowego wyciszenia jest wyzbycie się wszelkich trosk, a także gorliwa modlitwa: ona zaś jest wtedy, gdy stajemy do niej oraz gdy mamy nienaruszalne działanie serca". Лествица возводящая на небо, s. 277-424. Por. J. Naumowicz, Filokalia, s. 283-295.

38 Święty Grzegorz przyjął teorię Makarego który głosił, że: „Serce kieruje całym organizmem. Kiedy bowiem łaska ogarnie wszystkie obszary serca, wówczas panuje ono nad wszelkimi myślami i członkami. W nim właśnie znajduje się rozum i wszystkie myśli duszy". Лествица возводящая на небо, s. 410; J. Naumowicz, Filokalia, s. 305-315. 
O tym, jak osiągnąć pokój serca, pisali także Kalikst i Ignacy Ksantopuloi. Jako autorzy podręcznika dotyczącego modlitwy Jezusowej, powołując się na dzieła dawnych ojców, zachęcali wszystkich do walki duchowej o pokój Boży we własnym sercu. Podjęli to zagadnienie $\mathrm{w}$ aspekcie ascetyczno-sakramentalnym. Ich zdaniem podstawą do osiągnięcia duchowego pokoju jest wiara, życie sakramentalne i dobre uczynki. Natomiast źródłem każdego duchowego zmagania jest pełne wiary przyzywanie imienia Pana Jezusa (por. J 15,5). Owocem takiej praktyki modlitewnej jest pokój i miłość, podobne, zdaniem Ojców, do dwóch promieni wychodzących od Stwórcy. Z tego też względu modlący się musi być wolny od wszelkiego gniewu i sporu (por. $1 \mathrm{Tm}$ 2,8), gdyż tylko taka modlitwa prowadzi do Boga, który jest Miłością

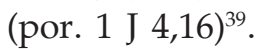

Ignacy i Kalikst należą do propagatorów stosowania w formule modlitwy Serca, odpowiedniego wysiłku. Pierwszy ruch - wdech, podczas wezwania: „Panie Jezu Chryste, Synu Boży”, gdy umysł wznosi się do Pana Jezusa, natomiast drugi - wydech, w końcowej frazie: „zmiłuj się nade mną grzesznikiem!", gdy umysł powinien do siebie powrócić. Dzięki temu wzorowi w przyszłości, w duchowości hezychastycznej zrodzi się praktyka dwuwymiarowego ruchu połączonego z rytmem oddechu ${ }^{40}$.

O praktycznym znaczeniu modlitwy Jezusowej dla człowieka pisał także atoski starzec Paisjusz, doświadczony ojciec duchowny mnichów i ludzi świeckich. Podkreślał on, że modlitwa Jezusowa stopniowo, opanowując duszę, wprowadza modlącego w stan ciszy, spokoju, czystości, radości i stałego wewnętrznego trwania przed Bogiem. Akcentował fakt, że tylko modlitwa Hezychii "może uspokoić i zadowolić człowieka" ${ }^{41}$.

Istotnym przymiotem modlitwy Jezusowej prowadzącej do pokoju serca jest fakt, że nie jest ona zarezerwowana tylko dla mnichów. Owszem wymaga odpowiedniego przygotowania i nastawienia, ale stan wyciszenia umysłu, czyli „modlitwa w sercu”, jest darem Ducha Świętego (por. Rz 8,26-27). On ułatwia spotkanie z Bogiem, zawiązuje ścisłą i dogłębną więź z Panem, owocującą ciszą i niebiańskim pokojem. Dzięki temu jest możliwa dla każdego, kto się otworzy na działanie Ducha Świętego. $\mathrm{Z}$ kolei temu, kto rozpoczął już mistyczną drogę do serca, autentyczna

${ }^{39}$ Por. J. Naumowicz, Filokalia, s. 326.

${ }^{40}$ Por. tamże, s. 327-335.

${ }^{41}$ Por. H. G. Krańczuk, Atoski starzec Paisjusz, Hajnówka 1997, s. 35. 
modlitwa powinna pomóc stać się całopalną ofiarą z siebie dla Boga (por. Ps 62,2.6) $)^{42}$.

Podsumowując, można uznać hezychię za jeden z podstawowych owoców modlitwy Jezusowej. Ojcowie z Góry Athos podkreślają jej biblijne, trynitarne i prawosławne korzenie. Dostrzegają również znaczenie rozpowszechnienia jej na chrześcijańskim zachodzie. Twierdzą, że istotą hezychii jest stan spokoju, wyciszenie ciała, serca i ducha, wewnętrzne skupienie i milczenie. Hezychia to także stan jedności ciała, ducha i duszy, gwarantujący modlącemu się mnichowi wewnętrzną ciszę i pokój. Dlatego w celu jej uzyskania Ojcowie podkreślają potrzebę praktykowania z wiarą modlitwy Jezusowej. Jako pomocne uznają czytanie i rozważanie Pisma Świętego, z jednoczesnym wysiłkiem ascetycznym: kierowania umysłu ku Bogu, uwalniania się od natrętnych myśli i namiętności. W taki sposób modlitwa Jezusowa doprowadzi do wewnętrznego wyciszenia człowieka, skierowania myśli na Boga i przemiany życia. Można zatem stwierdzić, że autentyczny hesychazm prowadzi do szczęścia i światłości, gdzie pokój jest więzią Boga ze stworzeniem, a przykład jego praktykowania, podany przez Ojców z Góry Athos, może stanowić doskonałą odpowiedź na poszukiwanie przez dzisiejszych chrześcijan, i nie tylko, sposobu modlitwy, który pozwoli uciec od natłoku spraw, znaleźć wyciszenie i odnaleźć relację z Bogiem.

Streszczenie. Artykuł poświęcony jest hezychii, która powszechnie uważana jest za jeden z podstawowych owoców modlitwy Jezusowej, Ojcowie z Góry Athos podkreślają jej biblijne, trynitarne i prawosławne korzenie. Twierdzą, że istotą hezychii jest stan spokoju, wyciszenie ciała, serca i ducha, wewnętrzne skupienie i milczenie. Hezychia to także stan jedności ciała, ducha i duszy, gwarantujący modlącemu się mnichowi wewnętrzną ciszę i pokój. Dlatego w celu jej uzyskania Ojcowie podkreślają potrzebę praktykowania z wiarą modlitwy Jezusowej. Jako pomocne uznają czytanie i rozważanie Pisma Świętego, z jednoczesnym wysiłkiem ascetycznym: kierowania umysłu ku Bogu, uwalniania się od natrętnych myśli i namiętności. W taki sposób modlitwa Jezusowa doprowadzi do wewnętrznego wyciszenia człowieka, skierowania myśli na Boga i przemiany życia.

Słowa kluczowe: hezychia; modlitwa Jezusowa; mnisi z Góry Athos.

Abstract. Isychast as a fruit prayer of the heart by letters selected fathers XII XIV century of Mount Athos. To sum up it is possible to recognize too isy-

${ }^{42}$ Por. G. Maloney, Modlitwa, s. 47-48. 53-57. 
chia behind one of basic fruits of the of Jesus prayer. Fathers from Mount Atos are emphasize for her biblical, Trinity and Orthodox roots. They also notice the significance of spreading for her on the Christian west. They claim (argue), that with being isychia there are a condition of the peace, quietening the body, the heart and the soul, an internal concentration and a silence. Isychia is also a condition of the unity of the body, mind and the soul, guaranteeing the praying monk internal silence and pace They claim, that with being isychia there are a condition of the peace, quietening the body, the heart and the ghost, an internal concentration and a silence. Isychia is also a condition of the unity of the body, the ghost and the soul, guaranteeing the praying monk internal silence and a piece. Therefore in the destination for her to get Fathers are emphasizing the need of practicing the of Jesus prayer with the faith. As helpful will recognize reading and considering (meditating) the Bible, with simultaneous ascetic effort; to lead the mind towards God, freeing oneself of obsessive thoughts and passion. This way of Jesus prayer will take the human to the internal calm, referrals thoughts to God and life transformations. Can be constitute the perfect answer to the search by Christian how to pray, which will escape from the multitude of matters and to find calm.

Keywords: isychia; prayer of the heart; monks from Athos Mountain. 